\title{
First Record of the Subfamily Methochinae (Hymenoptera: Tiphiidae) from Korea
}

\author{
Jeong-Kyu Kim* and Seung-Pil Han \\ Department of Biological Sciences, Faculty of Science, Hanseo University, \\ Chungcheongnam-do 356-706, Korea
}

\begin{abstract}
First discovery of Methocha articulata (Latreille) in Korea is reported. This species is transpalaearctic in distribution, and in the Far East only known from the Russian Far East so far. Diagnostic characters and digital images of this species are provided.
\end{abstract}

Keywords: Methochinae, Methocha articulata, Korea

\section{INTRODUCTION}

Methochinae is one of seven tiphiid subfamilies (Brothers and Finnamore, 1993). It comprises 63 extant species with worldwide distribution except for Australian region (Agnoli, 2010). Members of this subfamily are known for their extreme sexual dimorphism, and characterized by the combination of following features: male fore wing with two submarginal cells (Fig. 1A); anal lobe of hind wing shorter than submedian cell; antennae arising beneath small frontal tubercles (Fig. 1C); clypeus with a median process near base (Fig. 1B); tegula not covering axillary sclerites of forewing; dorsal surface of propodeum without enclosed median areola, rounding gradually into posterior surface (Fig. 1J); eighth sternum protruding as a stout reflexed aculeus; female wingless, antlike in general habitus; tibial spur formula 1-1-1; mesosternum truncate posteriorly and with a tooth or rounded angle in front of mid coxa; inner angle of mid coxa not overlaid by a triangular lamella; pygidial area glossy and relatively impunctate (Kromvein, 1982).

The subfamily Tiphiinae is the only tiphiid wasps so far known in Korea (Han and Kim, 2009). Recently we found several Korean male specimens of Methochinae identified as Methocha articulata (Latreille). In the present study, we firstly list this species as new record of the Korean tiphiid fauna, with diagnostic description complemented by digital images. Female diagnostic characteristics for the genus (Methocha) quoting from Kromvein (1982) are also given.

Terminology primarily follows Kromvein (1982). All measurements are taken at the maximal portion of the structure

*To whom correspondence should be addressed

Tel: 82-41-660-1349, Fax: 82-41-688-3403

E-mail: kwasp@hanseo.ac.kr being measured. Body length means the length from the anterior margin of head to posterior margin of metasomal tergum VIII. We use three comparative terms to explain puncture distribution: sparse (punctures spaced distantly, usually separating one another by two or three times as long as puncture diameter), moderate (punctures spaced by the puncture diameter), and dense (punctures spaced closely, usually punctures touching one another).

Abbreviations are used instead of administrative provincial division in full as follows: [CN] Chungcheongnam-do, [GB] Gyeongsangbuk-do, [GN] Gyeongsangnam-do.

All the voucher specimens used herein are housed at Insect Diversity Lab. in Hanseo University (HUIDL), Seosan-si, Korea.

\section{SYSTEMATIC ACCOUNTS}

$1 *$ Family Tiphiidae

2*Subfamily Methochinae

$3 *$ Genus Methocha Latreille

Methocha Latreille, 1804: 269. Type species: Mutilla articulata Latreille, 1792, designated by Agnoli, 2005: 36.

Diagnosis. Hind tibia with posterior apical spur distinctly Sshaped in both sexes. Male body long and slender (Fig 1A); tegula short, its end not reaching transcutellar suture; metasoma with long upwardly hooked sting; metasomal sternum VI shorter than sternum V, and not reaching the apex of pygidium; sternum VII partly exposed. Female apterous; prothorax, mesothorax, and metathorax-propodeum forming distinct, similar, and almost equal regions separated by marked constrictions; metathorax-propodeum almost globose; legs

$1 *$ 굼벵 이벌과, ${ }^{2 *}$ 호리굼벵 이벌아과 (신칭), ${ }^{3 *}$ 호리굼벵 이벌속 (신칭) 


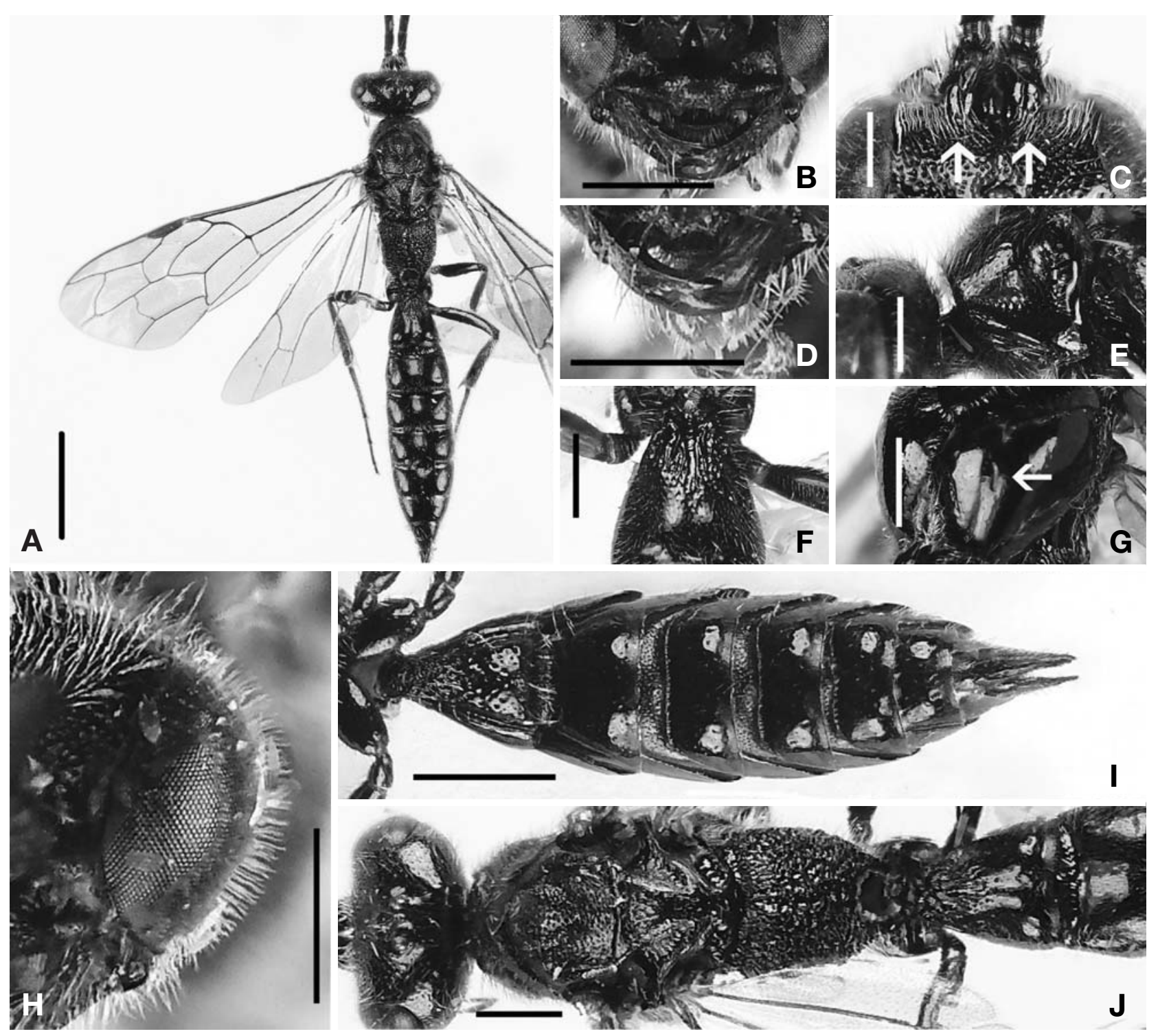

Fig. 1. Methocha articulata (Latreille), $0^{7}$. A, general habitus; B, clypeus; C, Frontal tubercles (arrows); D, mandible; E, lateral face of pronotum; $F$, anterior carina of metasomal tergum I; G, ventrolateral part of mesopleuron with fovea (arrow); $H$, eye covered with long bristles; I, metasomal sterna; J, mesosoma, dorsal view. Scale bars $=1 \mathrm{~mm}(A), 0.5 \mathrm{~mm}(B-J)$.

elongated.

Biology. All species of Methocha parasitize the larvae of cicindelid beetles dwelling in perpendicular burrows in the ground (Iwata, 1936; Kromvein, 1982; Agnoli, 2005).

\section{$1 *$ Methocha articulata (Latreille)}

Mutilla articulata Latreille, 1792: 100.

Methocha articulata (Latreille): Latreille, 1804: 269; Agnoli, 2005: 37[confirmed the valid name of articulata against accepted name of ichneumonides, and provide detailed synonymic lists].

Diagnostic description. Male. Body length 7.0-7.4 mm (Fig. 1A). Body long and slender; seen from above, head wider than mesosoma and metasoma. Interantennal area medially with small process. Frontal tubercle (Fig. 1C, arrow) truncated apically, and forming horizontal face equipped with dense (touching one another) large punctures. Antennal flagellum 1 shortest, about $2 / 3$ of flagellum 2; flagella 2-13 subequal in length; each flagellum somewhat bent, but last five flagella

\footnotetext{
$1 *$ 호리굼벵 이벌 (신칭)
} 
more distinctly bent. Apicomedian production of clypeus trapezium in shape, and its apical margin emarginated (Fig. 1B). Mandible bitoothed including apical one (Fig. 1D). Pronotal carina absent; posterior margin of pronotum widely arcuated; lower part of lateral face of pronotum widely depressed, and its bottom costate (Fig. 1E). Median part of basal $2 / 3$ of mesoscutum weakly swollen, forming shield-like structure. Parasidal lines and posterior groove of mesoscutum connected. Ventral part of mesopleuron with a pair of roundish linear foveae (Fig. 1G, arrow). Epicnemial carina strongly developed (highly raised), and complete without interruption. Transsautellar groove wide (almost same in length throughout the groove), and deeply excavated. Basomedian part of metasomal tergum I with four carina: inner two ones parallel and outer two ones slightly divergent (Fig. 1F).

Vertex polished, with very sparse punctures irregularly set. Upper frons, except for smooth and polished interantennal socket and just above areas, densely punctate. Basal half of pronotal dorsum, except for median part, densely punctate, and remaining part smooth and polished. Mesoscutum coarse, with both short transverse carinae and punctures. Scutellum with sparse punctures irregularly set, and interspaces polished. Larger part of propodeal dorsum reticulate, and larger part of posterior propodeal face carinate (Fig. 1J). Metasomal terga I-VII smooth (almost impunctate, at most with tiny sparse punctures) and polished. Sternum I moderately to densely punctate. Sternum II polished and almost impunctate. Sterna III-VI with very densely punctate in their basal $1 / 3$ (pre-circus area), and remaining parts polished and almost impunctate (Fig. 1I).

Eye covered with conspicuous long bristles (Fig. 1H). Body covered with only whitish bristles and hairs.

Body black, but legs and tegula light brown.

Female unavailable in this study.

Specimens examined. [CN] 1 ऽ , Daejeon-si, Yuseong-gu, Jang-dong, 17 Jun.-23 Jun. 1996, Pierre Tripotin (Malaise trap); 1 Ћ , Buyeo-gun, Gyuam-myeon, Sumok-ri, 1 Apr.-15 Apr. 2005, J.W. Lee (Malaise trap) [GB] $1 \sigma^{\top}$, Gyeongsan-si, Dae-dong, 5 Sep. 1989, J.W. Lee [GN] $2 ð^{\nearrow}$ ð, Jinju-si, Daepyeong-myeon, 28 Aug. 1992, collector not written; $1 \sigma^{\nearrow}$, Naehae-gun, Sandong-myeon, Bonghanri Jayeonhyuyamrim, 20 Jun. 2000, JS Choi.

Distribution. Transpalaearctic: Europe (Agnoli, 2005) to
Eastern Russia (Gorbatovskij, 1995) and Korea (new record).

\section{ACKNOWLEDGEMENTS}

Some specimens used here were provided by Professor JW Lee (Yeungnam Univ.) and emeritus Professor JS Park (Gyengsang Univ.). This work was supported by the Survey of Indigenous Biological Resources of Korea Project, NIBR.

\section{REFERENCES}

Agnoli, G.L., 2005. The Genus Methocha in Europe: a discussion on taxonomy, distribution and likely origin of its known species and subspecies (Hymenoptera Tiphiidae Methochinae). Bulletine of Insectology, 58(1): 35-47.

Agnoli, G.L., 2010. http://www.chrysis.net/methocha.html. (interim version 10-Jan-2010).

Brothers, J. and T. Finnamore, 1993. Superfamily Vespoidea. In: Hymenoptera of the world: An identification guide to families (Eds., H. Goulet and T. Huber). pp. 161-232. Research Branch Agriculture Canada Publication 1894/E.

Gorbatovskij, V.V., 1995. Family Tiphiidae. In: Key to the insect of Russian Far East, Vol. VI, Ed in Neuroptera, Mecoptera, Hymenoptera. Part I(Ed., P.R. Lehr). pp. 196-202. St. Petersberg, Nanka.

Han, S.P. and J.K. Kim, 2009. Taxonomic review of the family Tiphiidae (Hymenoptera: Vespoidea) in South Korea. Animal Cells and Systems, 13: 247-263.

Iwata, K., 1936. Biology of two Japanese species of Methocha, with the description of a new species. Kontyu, 10: 57-89.

Kromvein, K.V., 1982. Biosystematic studies of Ceylonese Wasps, IX: A monograph of the Tiphiidae (Hymenoptera: Vespoidea). Smithsonian Contributions to Zoology, 374: 1132.

Latreille, P.A., 1792. Description de deux nouvelles espèces des Mutilles. In: Lamarck, Bruguière, Olivier Hauy et Pelletier, Journal d'Histoire Naturelle, Paris, Tom II: 98-101.

Latreille, P.A., 1804. Tableau méthodique des insects. Classe huitième. Insectes, Insecata. In: Vouveau Dictionnaire d' Historie Naturalle, 24, Paris, France, pp. 129-200.

Received February 10, 2010 Accepted March 11, 2010 